\title{
On Happiness in Teaching: An Ordered Logit Modeling Approach
}

\author{
Leomarich F. Casinillo1, Emily L. Casinillo ${ }^{{ }^{\star}}$, Maita F. Casinillo ${ }^{3}$ \\ 1,2Department of Mathematics and Physics, Visayas State University, Baybay City, Leyte, Philippines \\ ${ }^{3}$ Hilongos National Vocational School, Hilongos Leyte, Philippines \\ e-mail: leomarich_casinillo@yahoo.com, elagumbay12201990@gmail.com,maita.casinillo@yahoo.com
}

\begin{abstract}
This study was conducted to explain the degree of happiness in teaching and determine its influencing socio-economic factors. Using a probabilistic sampling method, the study employed 127 junior and senior high school teachers as respondents. Primary data were collected through developed questionnaires and analyzed using descriptive measures and ordered logit modeling. Results showed that this study documented a statistically significant determinant of the feeling of happiness in teaching, namely: other sources of income, creative and enjoyable teaching experience, school compound, social relationship, and health condition. Having other sources of income has an inverse effect on the happiness of teachers, this might be due to additional responsibilities while serving the students. The study showed that teachers are more likely happy if they found their job as creative and enjoyable which positively influences their well-being and professional growth. There is also a higher chance of being happy if the school environment is conducive for learning and provides comfort to teachers. Furthermore, being socially oriented and the healthy teacher are productive and efficient in work which is more likely to be happy.
\end{abstract}

Keywords: Happiness In Teaching; Socio-Economic Factors; Probabilistic Sampling; Ordered Logit modeling

\section{Introduction}

Education is the most important aspect of individual development in the country (Ghavifekr \& Rosdy, 2015). Nowadays, the attention on the development of education is strictly increasing using innovative technologies, to promote not just the well-being of learners but also the teachers. The study of Singh (2014) states that according to educators, happiness in the teaching-learning process is a primary objective of education. Happiness in teaching is one of the most valuable things in a classroom setting and it's hard to imagine a teacher who doesn't yearn to be happy facing and imparting their knowledge to students. Teachers, being the captain in the learning process, must employ activities and teaching strategies that promote positive learning outputs and well-being to students in the classroom settings. The teacher and the teaching strategy employed plays an important role in developing the individual to social, emotional, and mental skills (Casinillo \& Guarte, 2018). According to Guazzelli and Zilli (2016), teachers who are happy working have a high likelihood that school provides a stimulating environment for the students. The study of Guazzelli and Zilli (2016) complemented with the study of Chaiprasit and Santidhirakul (2011), and Mertoğlu (2018), they state that improving the school environment, benefits, facilities and creating a positive institutional climate can make a significant contribution to the happiness and well-being of teachers. Hence, school administration affects teachers' well-being which further promotes positive learning outputs to the learners. The study of Schiffrin \& Nelson (2010), has revealed that teachers who have low-stress levels are more likely happy in teaching which results in productivity and effectivity in imparting learnings to the students.

The study of Frey and Stutzer (2010) stated that the economics of happiness is based on recognizing that the individual has their ideas about happiness and the good quality of life. In effect, a happy teacher is more likely to act healthy and efficient in the teaching-learning process and helps learners to become good human, and influential being in the society (Guazzelli \& Zilli, 2016). In the town of Hilongos, Leyte, Philippines, Hilongos National

\footnotetext{
* Corresponding author.

Received 19 May 2020; Accepted 22 June 2020; Available online 20 June 2020

(C) 2020 JPI. All Rights Reserved
} 
Vocational School (HNVS) is one of the eight autonomous technical-vocational schools in the division of Leyte, which in turn, one of the 13 divisions in the Eastern Visayas Region in the Philippines. HNVS is along the national highway and very proximate to the town proper. Its resources and amenities are relevant to the needs of the learners which are relatively within reach. HNVS has been serving the academic and vocational training needs of junior and senior high school students of Hilongos as well as those from the neighboring municipalities. Investigating the well-being among teachers in HNVS has never been done which is a crucial factor in the productive teaching process. It is worth noting that happiness at teaching has been mainly approached concerning the effects of the features of the school environment, leading attention to the cognitive and emotional processes (Mertoğlu, 2018). Perhaps, it has emerged that the main factors leading happiness at teaching are interpersonal relationships with colleagues, heads, and even students (Macuka et al., 2017). Satisfaction in work is vital that people need to have so that they can be happy in their lives which results in productivity (Dağli and Baysal, 2017; Proto, 2016). Satisfaction and happiness are definite as the positive development of the qualities of the work of an individual. Some studies reveal that happiness of a worker is influenced by demographic profile (Guazzelli \& Zilli, 2016), income and personal assets (Frey \& Stutzer, 2010; Helliwell et al., 2012), workplace (Singh, 2014), awards for the accomplishments (Fisher, 2010), fair treatment at teaching loads (Chaiprasit \& Santidhirakul, 2011), leisure activities (Wolf \& Beblo, 2004), positive social relationships and family (Golden et al., 2013; Štreimikienè and Grundey, 2009), and even good health (Andersson, 2008). Hence, Figure 1 shows the framework of this study.

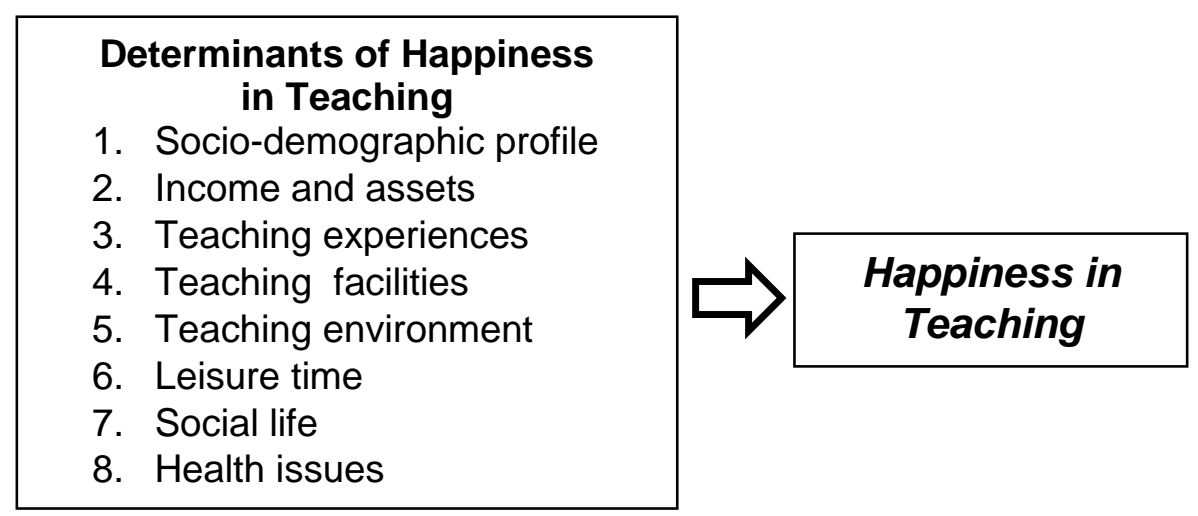

Figure 1. The theoretical framework of the study.

Though happiness is a personal asset of a teacher, its implications to education are valuable and diverse. Knowing that happiness of teachers is characterized by their profile, then this work wants to understand the implications of socio-economic factors on the feeling of happiness. In detail, the purpose of this paper is to measure the level of happiness of high school teachers in HNVS concerning its influencing economic factors. Hence, the present study aims to expand the understanding of happiness of the teachers and concerning their socio-demographic profile, income, and assets, work experience, work environment, leisure time, social relationships, and health. Furthermore, this study was conducted to document and highlight statistically significant determinants that might impact the degree of happiness to improve some existing policy at the secondary level of education and assess the needs of public teachers. In the study of Akomolafe and Ogunmakin (2014), it is stated that being happy and job satisfied in teaching received much attention from the educational system to develop an existing policy. To date, limited studies are available about establishing a connection between the well-being of high school teachers and their socio-economic profile using ordered logit modeling, thus, the aim is also to contribute to the literature.

Generally, this study aims to model and investigate different socio-economic factors of happiness of being a high school teacher. Using ordered logit modeling, the study deals on determining the statistically significant factors of happiness and specifically sought the following objectives: 1) to estimate the level of happiness of these teachers and describe the 
socio-demographic profile of high school teachers; and 2) to document significant determinants affecting the degree of happiness of the teachers using ordered logit models.

\section{Method}

\subsection{The Research Design}

The research design of this study was based on the study of Guazzelli and Zilli (2016), and Mertoğlu (2018) that deals with determining significant determinants of happiness which involves inferential methods. Primary data was collected on the socio-demographic profile, level of happiness, and its influencing determinants using structured questionnaires. In describing the data, descriptive measures were used such as percentages, minimum, maximum, mean, and standard deviation. For further analysis, ordered logit modeling was constructed to determine the significant socio-economic factors of the well-being of the teachers, and the interpretation of the model is founded in the study of Williams (2016).

\subsection{The Respondents, Sampling Method, and Ethical Procedure}

The population of interest was all currently active junior and senior high school teachers in HNVS during the conduct of the study. A probabilistic approach was considered in this study for sample size determination and used the following formula (Cochran, 1953):

$$
n_{0}=\frac{Z_{\alpha / 2}^{2} \sigma^{2}}{e^{2}}
$$

where $n_{0}$ is the sample size, $Z_{\alpha / 2}$ is the confidence interval, $\sigma^{2}$ is the population variance and $e$ is the margin of error. In this study, the confidence interval used is $95 \%$, which suggests that the sample is certain $95 \%$ of the time. The established $Z$-value for the $95 \%$ confidence interval is 1.96. There is no prior information for the population variance $\sigma^{2}$ in this study, hence, it was estimated using proportions. It was assumed that the proportion would be 0.5 since there is limited information available in the teachers in HNVS and it was considered that the margin of error is $2.5 \%$. Thus, the sample size was determined as follows:

$$
n_{0}=\frac{Z_{\alpha / 2}^{2}(0.5)(1-0.5)}{e^{2}}
$$

Since the population is known to be finite, then the adjusted sample size can be computed as follows:

$$
n=\frac{n_{0}}{1+\frac{n_{0}}{N}}
$$

where $n$ refers to the adjusted sample size, $n_{0}$ refers to the initial sample size and $N$ is the number of teachers in the HNVS. In the determination of teachers to be interviewed, a list of all teachers was obtained from the office of the human resource of the school. The result $n$ in (3) was allocated to the junior and senior high teachers. The junior and senior high teachers were considered as strata and in choosing the desired respondent, a simple random sampling was used for each stratum. An alternative teacher was drawn in case the selected teacher is not available or refuses to participate in the interview. Table 1 shows the distribution of sample teachers. 
Table 1. Distribution of High School Teachers in Terms Teaching Level

\begin{tabular}{cccc}
\hline Teaching Level & $\begin{array}{c}\text { Number of } \\
\text { Teachers }\end{array}$ & $\begin{array}{c}\text { Sample } \\
\text { Size }\end{array}$ & $\begin{array}{c}\text { Percentage } \\
(\%)\end{array}$ \\
\hline Junior High Level & 104 & 96 & 92.31 \\
\hline Senior High Level & 34 & 31 & 91.18 \\
\hline Total & 138 & 127 & 92.03 \\
\hline
\end{tabular}

This study considers ethical procedure, hence, the participation of the said survey was voluntary. Before the conduct of the study, teachers were assured that all data gathered were treated with high confidentiality and solely used for research purposes. Furthermore, teachers who participated in this study were protected by not disclosing names and sensitive information that could potentially recognize any of them.

\subsection{The Data Gathering and Survey Instruments}

The permission of the school principal in HNVS was asked before the conduct of the study. This study utilized primary data through a self-completed, semi-structured questionnaire to determine the socio-demographic profile, level of happiness in teaching, and its influencing economic determinants among high school teachers. The said questionnaire contains a mixture of open-ended and closed-ended peer-reviewed questions designed to collect a variety of information to fulfill the aims of this study (Sharp, 2012). For demographic profile, the teachers were asked about the following: age, gender ( $1=$ male, $0=$ female), Hometown ( $1=$ Urban, $0=$ Rural), number of years in education, married life ( $1=$ Married, $0=$ Not married), household size, monthly income, another source of income ( $1=$ Yes, $0=\mathrm{No})$, household assets and monthly household expense. Another 12-item scale aimed at assessing the other determinants of happiness in teaching was asked using a 10-point Likert scale, that is, 1-Very unsatisfied and 10- Very satisfied. The questions are focusing on the following: Teaching experience (Routinely, Creative, Challenging, Enjoyable, Logical and Rewarding), Classroom facilities, school library, school compound, leisure time, social relationship, and health issues. The following economic profile was adopted from the early studies of Guazzelli \& Zilli (2016) and Mertoğlu (2018) which is designed to document the implications of different determinants on the degree of happiness among teachers. The questionnaire on the level of actual happiness in teaching is based on the study of Lyubomirsky and Lepper (1999) that was designed to measure subjective happiness and has undergone pre-testing and reliability tests. The teachers were asked regarding their over-all happiness in teaching. This is completed by choosing a scale from 1 to $10: 1$ is a very unhappy teacher and 10 a very happy teacher. Perhaps, it was found out that this instrument was valid and reliable.

\subsection{The Data Analysis and Ordered Logit modeling}

In data analysis, first, descriptive statistics were computed in describing and evaluating the dependent and independent variables in this study. With the aid of SPSS v.20, the following descriptive measures such as mean, standard deviation, the minimum, and the maximum value was obtained. In determining the significant factors of happiness in teaching, an ordered logit model was constructed. An ordered logit model is an econometric model that is also ordered logistic regression or proportional odds model is an ordinal regression model that deals with ordinal dependent variables (Stock \& Watson, 2007). This model is an extension of the logistic regression model that applies to dichotomous dependent variables, which allows more than two ordered response categories. Thus, the ordinal response $H_{i}$ (Scale of 1 to 10$)$ for $i^{t h}$ teacher and with $k$ categories $(k=0,1,2, \ldots, 9)$ is defined by two equations where the cumulative probabilities are defined by

$$
g_{c i}=\operatorname{Pr}\left(H_{i}\right) \leq\left(k \mid x_{1}, x_{2}, \ldots, x_{n}\right)
$$

where $H_{i}$ is the actual happiness for $i^{t h}$ teacher and $n$ is the number of explanatory variables. 
Let $\beta^{\prime} X_{i}=\beta_{1} x_{1}+\beta_{2} x_{2}+\cdots+\beta_{n} x_{n}+\varepsilon_{i}$ be a linear predictor. Then, the ordered logit function can be written as:

$$
\operatorname{logit}\left(g_{k i}\right)=\log \left(\frac{g_{k i}}{1-g_{k i}}\right)=\alpha_{k}-\beta^{\prime} X_{i}
$$

where $x_{1}, x_{2}, \ldots, x_{n}$ are independent variables such as demographic profile and other determinants of happiness, $\alpha_{k}$ is a parameter called thresholds or cut points and it is increasing order, that is, $\alpha_{1}<\alpha_{2}<\cdots<\alpha_{k-1}$. A vector $\beta$ of parameters to be estimated and $X_{i}$ is a vector of factors or predictors. From equation (8), the given cumulative probability for category $k$ is given by

$$
g_{k i}=\frac{e^{\alpha_{k}-\beta^{\prime} X_{i}}}{1+e^{\alpha_{k}-\beta^{\prime} X_{i}}}=\frac{1}{1+e^{-\alpha_{k}+\beta^{\prime} X_{i}}}
$$

The parallel regression assumption implies the proportionality of the odds of not exceeding the $k^{\text {th }}$ category, that is, odds $s_{k i}=\frac{g_{k i}}{1-g_{k i}}$. The ratio of these odds for two units say $i$ and $j$, is given by

$$
\frac{o d d s_{k i}}{o d d s_{k j}}=e^{\left[\beta^{\prime}\left(X_{j}-X_{i}\right]\right.}
$$

And this is constant across response categories (Stock \& Watson, 2007). The probabilities of the categories $k$ are obtained by difference:

$$
P_{k i}=\frac{1}{1+e^{-\alpha_{k}+\beta^{\prime} X_{i}}}-\frac{1}{1+e^{-\alpha_{k-1}+\beta^{\prime} X_{i}}}
$$

Some diagnostic tests for the econometric models were performed to ensure valid results for interpretation such as multicollinearity test, homoscedasticity test, omitted variables test, and normality test for residuals (Casinillo \& Aure, 2018; Greene, 2008). To ensure an accurate calculation, this study used a statistical software called STATA v.14.

\section{Findings}

\subsection{Descriptive Analysis of the Survey}

In Table 2, shows that the actual happiness of high school teachers can be described as very happy $(\mu=8.17, \sigma=1.36)$. The age of the teachers ranges from 22 to 61 years old $(\mu=37.43, \sigma=11.14)$, and there are $33.86 \%$ males and $66.14 \%$ females. About $44.88 \%$ of the teachers live in urban places and $55.12 \%$ live in rural areas. The number of years in the education of the high school teachers ranges from 14 to 20 ( $\mu=15.41, \sigma=1.64)$. On average, $65.35 \%$ of the teachers are married and their household size ranges from 1 to $11(\mu=4.36$, $\sigma=1.83$ ). The average monthly income of the teachers was 23,763.90 PhP (Min=2,217, Max $=45,000)$ and about $29.13 \%$ of them has other source of income. Their household assets ranges from 10,000 $\mathrm{PhP}$ to $1,233,000 \mathrm{PhP}(\mu=177,004.30, \sigma=218,132.10)$ and their monthly household expense is approximately equal to $25,650.40 \mathrm{PhP}$. The teachers are satisfied with the following experiences: routinely $(\mu=8.55, \sigma=1.44)$, creative $(\mu=7.91, \sigma=1.68)$, challenging $(\mu=8.49, \sigma=1.59)$, enjoyable $(\mu=8.27, \sigma=1.81)$, logical $(\mu=7.98, \sigma=1.67)$, and rewarding $(\mu=8.26, \sigma=1.86)$. The teachers are satisfied with the school facilities $(\mu=6.91, \sigma=2.03)$ and compound $(\mu=6.91, \sigma=1.99)$. However, teachers was not satisfied to their school library $(\mu=3.89, \sigma=2.44)$ due to lack of resources. Results reveal that teachers are active in leisure activities $(\mu=7.31, \sigma=1.86)$ and socially $(\mu=7.87, \sigma=1.58)$ oriented in their family and school campus. Furthermore, results also shows that these teachers are physically and mentally healthy $(\mu=8.06, \sigma=1.52)$. 
Table 2. Descriptive Measures for Actual Happiness and Its Influencing Determinants of High School Teachers $(n=127)$

\begin{tabular}{|c|c|c|c|c|}
\hline Variables & Mean & Min & Max & Std. Dev. \\
\hline Actual Happiness ${ }^{\mathrm{a}}$ & 8.1654 & 5 & 10 & 1.3556 \\
\hline Age (in years) & 37.4330 & 22 & 61 & 11.1367 \\
\hline Male (dummy) & 0.3386 & 0 & 1 & 0.4751 \\
\hline Urban (dummy) & 0.4488 & 0 & 1 & 0.4993 \\
\hline Years in education (in years) & 15.4095 & 14 & 20 & 1.6397 \\
\hline Married (dummy) & 0.6535 & 0 & 1 & 0.4777 \\
\hline Household size & 4.3622 & 1 & 11 & 1.8286 \\
\hline Monthly income $e^{b}$ & 23763.9 & 2217 & 45000 & 5696.019 \\
\hline Other source of income (dummy) & 0.2913 & 0 & 1 & 0.4562 \\
\hline Household assets ${ }^{b}$ & 177004.3 & 10000 & 1233000 & 218132.1 \\
\hline Monthly Household expense ${ }^{b}$ & 25650.4 & 6100 & 226500 & 31386.77 \\
\hline Teaching experience: Routinely ${ }^{a}$ & 8.5512 & 1 & 10 & 1.4404 \\
\hline Teaching experience: Creative $\mathrm{a}^{\mathrm{a}}$ & 7.9134 & 1 & 10 & 1.6763 \\
\hline Teaching experience: Challenging a & 8.4882 & 1 & 10 & 1.5930 \\
\hline Teaching experience: Enjoyable ${ }^{\mathrm{a}}$ & 8.2677 & 1 & 10 & 1.8058 \\
\hline Teaching experience: Logical ${ }^{\mathrm{a}}$ & 7.9764 & 1 & 10 & 1.6736 \\
\hline Teaching experience: Rewarding ${ }^{a}$ & 8.2598 & 1 & 10 & 1.8611 \\
\hline Classroom/facilities ${ }^{\mathrm{a}}$ & 6.9055 & 1 & 10 & 2.0293 \\
\hline School library ${ }^{\mathrm{a}}$ & 3.8976 & 1 & 10 & 2.4425 \\
\hline School compound ${ }^{a}$ & 6.9055 & 2 & 10 & 1.9977 \\
\hline Leisure time $^{\mathrm{a}}$ & 7.3071 & 2 & 10 & 1.8581 \\
\hline Social relationship ${ }^{a}$ & 7.8661 & 2 & 10 & 1.5804 \\
\hline Health condition ${ }^{\mathrm{a}}$ & 8.0551 & 2 & 10 & 1.5239 \\
\hline
\end{tabular}

Note: $\quad a$-Scale 1 to $10 ; b$ - Philippine Peso (PhP)

\subsection{Ordered logit Models}

Table 3 highlights the 3 ordered logit models that explained the statistically significant determinants of happiness in teaching. The 3 models are developed through the interactions between variables and based on the random heterogeneity of the sample. Diagnostic tests are employed for the 3 models to determine whether the necessary assumptions were valid before performing inference to the parameters of interest (O'Connell \& Liu, 2011). The Breusch-Pagan test indicated that the first model is heteroskedastic $\left(\chi^{2}=25.84, p\right.$ value $<0.001)$ and the model has omitted variables bias $(F=1.53, p$-value $<0.001)$ by Ramsey RESET test (Table 3 ). Thus, the first model was corrected and adjusted to account for heteroscedasticity and omitted variable bias until the model does need more variables.

For the multicollinearity test in the model, Variance Inflation Factor (VIF) was computed which estimates how much the variance of a coefficient is inflated because of linear dependence with other predictors (Allison 2012). Then, as a rule of thumb, mean VIF value should be lesser than 10 to safely ignore a multicollinearity problem in the model. Hence, there is no multicollinearity problem in the first model since the mean VIF is equal to 1.76. The residuals are not normal by Shapiro-Wilk test $(Z=4.18, p$-value $=0.035)$ which rejects the null hypothesis that the residuals are normal. However, the Kernel density estimate graph shows that the residuals are almost normal. The model $\left(\chi^{2}=73.26\right)$ is also significant since $p$-value is less than 0.001 which implies that all coefficients taken together is not equal to zero. The independent variables that significantly influence the happiness in teaching in Model 1 are the teachers' other source of income $(Z=-1.66, p$-value $=0.097)$, creative $(Z=2.11, p$-value $=0.035)$ and enjoyable $(Z=2.82, p$-value $=0.005)$ teaching experiences, school compound $(Z=2.50, p$ value $=0.013)$ and health conditions $(Z=1.97, p$-value $=0.049)$. By Breusch-Pagan test, it was found out that the variances of Model 2 is also heteroscedastic $\left(\chi^{2}=12.44, p\right.$-value $\left.<0.001\right)$ and by Ramsey RESET test $(F=1.44, p$-value $=0.069)$ the model has no omitted variables bias (Table 3). Thus, the second model was corrected and adjusted to account for heteroscedasticity problem. It was found out that the models had no problem of multicollinearity between pair of predictors (mean VIF=2.18<10). By Shapiro-Wilk test, it is 
revealed that the residuals are normal $(Z=3.91, p$-value $<0.001)$. But by Kernel density graph, it shows that the residuals are close to normality.

Model 2 is also significant $\left(\chi^{2}=25.84, p\right.$-value $\left.<0.001\right)$ which implies that the econometric determinants explain the variation of the actual happiness of the teachers. The significant determinants are the following: creative teaching experience $(Z=1.97, p$-value $=0.048)$, enjoyable teaching experience $(Z=3.47, p$-value $=0.001)$, social relationship $(Z=2.14, p$ value $=0.033)$, and health condition $(Z=1.95, p$-value $=0.051)$. For Model 3 , it is indicated that the model is heteroskedastic $\left(\chi^{2}=22.88, p\right.$-value $\left.<0.001\right)$ by Breusch-Pagan test and it was adjusted to account for heteroscedasticity (Table 3 ). Also, the model has omitted variables bias $(F=4.02, p$-value $=0.009)$ by Ramsey RESET test and it was corrected to remove the bias. There is no multicollinearity problem in the model (mean VIF $=1.57<10$ ). And by Shapiro-Wilk test, the residuals are not normal $(Z=3.633, p$-value $<0.001)$. However, it shows that the residuals are close to normality by the Kernel density estimate graph. As a whole the model is significant $\left(\chi^{2}=43.22, p\right.$-value $\left.<0.001\right)$, which implies that there are influencing factors of happiness in teaching. The following significant factors are: having other source of income $(Z=-2.44, p$-value $=0.015)$, school environment $(Z=2.38, p$-value $=0.017)$ and health conditions $(Z=2.83, p$-value $=0.005)$.

Table 3. Ordered Logit Models for High School Teachers' Actual Happiness as A Dependent Variable and Its Influencing Determinants $(n=127)$

\begin{tabular}{|c|c|c|c|c|c|c|}
\hline \multirow[b]{2}{*}{ Independent Variables } & \multicolumn{2}{|c|}{ Model I } & \multicolumn{2}{|c|}{ Model li } & \multicolumn{2}{|c|}{ Model lii } \\
\hline & $\begin{array}{c}\text { COEFFICI } \\
\text { ENT }\end{array}$ & $\begin{array}{c}S T D \\
\text { ERROR }\end{array}$ & $\begin{array}{c}\text { COEFFICI } \\
\text { ENT }\end{array}$ & $\begin{array}{c}S T D \\
\text { ERROR }\end{array}$ & $\begin{array}{c}\text { COEFFICI } \\
\text { ENT }\end{array}$ & $\begin{array}{c}S T D \\
\text { ERROR }\end{array}$ \\
\hline Senior High Teacher (dummy) & $\begin{array}{l}0.5168 \\
(0.394)\end{array}$ & $\begin{array}{l}0.4589 \\
(0.850)\end{array}$ & & & $\begin{array}{l}0.4774 \\
(0.372)\end{array}$ & $\begin{array}{l}0.4463 \\
(0.890)\end{array}$ \\
\hline Age (in years) & $\begin{array}{r}-0.0224 \\
(0.247)\end{array}$ & $\begin{array}{c}0.0217 \\
(-1.160)\end{array}$ & & & $\begin{array}{r}-0.0181 \\
(0.265)\end{array}$ & $\begin{array}{c}0.0182 \\
(-1.120)\end{array}$ \\
\hline Male (dummy) & $\begin{array}{l}0.0148 \\
(0.821)\end{array}$ & $\begin{array}{c}0.3937 \\
(-0.230)\end{array}$ & & & & \\
\hline Urban (dummy) & $\begin{array}{l}0.4423 \\
(0.190)\end{array}$ & $\begin{array}{c}0.3772 \\
(1.31)\end{array}$ & & & & \\
\hline Years in education (in years) & $\begin{array}{l}0.0505 \\
(0.973)\end{array}$ & $\begin{array}{l}0.1217 \\
(0.030)\end{array}$ & & & & \\
\hline Married (dummy) & $\begin{array}{r}-0.1315 \\
(0.713)\end{array}$ & $\begin{array}{c}0.4454 \\
(-0.370)\end{array}$ & & & & \\
\hline Household size & & & & & $\begin{array}{l}0.0361 \\
(0.661)\end{array}$ & $\begin{array}{l}0.0965 \\
(0.440)\end{array}$ \\
\hline Monthly income ${ }^{b}$ & $\begin{array}{c}7.53 e-06 \\
(0.744)\end{array}$ & $\begin{array}{c}0.00004 \\
(0.330)\end{array}$ & $\begin{array}{c}-5.93 e-06 \\
(0.845)\end{array}$ & $\begin{array}{l}0.00003 \\
(-0.200)\end{array}$ & $\begin{array}{c}-3.36 \mathrm{e}-06 \\
(0.955)\end{array}$ & $\begin{array}{l}0.00003 \\
(-0.060)\end{array}$ \\
\hline Other source of income (dummy) & $\begin{array}{c}-0.8212^{*} \\
(0.097)\end{array}$ & $\begin{array}{c}0.4806 \\
(-1.660)\end{array}$ & $\begin{array}{c}-0.4452 \\
(0.303)\end{array}$ & $\begin{array}{c}0.4319 \\
(-1.030)\end{array}$ & $\begin{array}{c}-0.9635^{\star *} \\
(0.015)\end{array}$ & $\begin{array}{c}0.4233 \\
(-2.440)\end{array}$ \\
\hline Household assets $^{b}$ & & & $\begin{array}{c}-5.54 \mathrm{e}-07 \\
(0.488)\end{array}$ & $\begin{array}{c}8.04 e-07 \\
(-0.690)\end{array}$ & & \\
\hline Monthly Household expense ${ }^{b}$ & & & $\begin{array}{c}8.37 \mathrm{e}-06 \\
(0.143)\end{array}$ & $\begin{array}{c}5.76 \mathrm{e}-06 \\
(1.460)\end{array}$ & & \\
\hline Teaching experience: Routinely ${ }^{a}$ & & & $\begin{array}{l}0.0133 \\
(0.929)\end{array}$ & $\begin{array}{l}0.1510 \\
(0.090)\end{array}$ & & \\
\hline Teaching experience: Creative $^{\mathrm{a}}$ & $\begin{array}{c}0.3299^{* *} \\
(0.035)\end{array}$ & $\begin{array}{c}0.1497 \\
(2.11)\end{array}$ & $\begin{array}{c}0.4488^{* *} \\
(0.048)\end{array}$ & $\begin{array}{l}0.2286 \\
(1.970)\end{array}$ & & \\
\hline Teaching experience: Challenging ${ }^{a}$ & & & $\begin{array}{l}-0.0019 \\
(0.993)\end{array}$ & $\begin{array}{c}0.2007 \\
(-0.010)\end{array}$ & & \\
\hline Teaching experience: Enjoyable ${ }^{a}$ & $\begin{array}{c}0.4061^{* * *} \\
(0.005)\end{array}$ & $\begin{array}{l}0.1363 \\
(2.820)\end{array}$ & $\begin{array}{c}0.4795^{\star * *} \\
(0.001)\end{array}$ & $\begin{array}{l}0.1390 \\
(3.470)\end{array}$ & & \\
\hline Teaching experience: Logical ${ }^{\mathrm{a}}$ & & & $\begin{array}{r}-0.0302 \\
(0.863)\end{array}$ & $\begin{array}{c}0.1730 \\
(-0.170)\end{array}$ & & \\
\hline Teaching experience: Rewarding ${ }^{\mathrm{a}}$ & & & $\begin{array}{c}-0.1606 \\
(0.320)\end{array}$ & $\begin{array}{c}0.1622 \\
(-0.990)\end{array}$ & & \\
\hline Classroom/facilities $^{\mathrm{a}}$ & $\begin{array}{l}0.0489 \\
(0.693)\end{array}$ & $\begin{array}{l}0.1207 \\
(0.390)\end{array}$ & & & $\begin{array}{l}0.1557 \\
(0.197)\end{array}$ & $\begin{array}{l}0.1205 \\
(1.290)\end{array}$ \\
\hline School library ${ }^{\mathrm{a}}$ & -0.0840 & 0.0878 & & & -0.0846 & 0.0813 \\
\hline
\end{tabular}




\begin{tabular}{|c|c|c|c|c|c|c|}
\hline & $(0.387)$ & $(-0.870)$ & & & $(0.284)$ & $(-1.070)$ \\
\hline School compound ${ }^{\mathrm{a}}$ & $\begin{array}{c}0.2925^{\star \star *} \\
(0.0130)\end{array}$ & $\begin{array}{l}0.1096 \\
(2.500)\end{array}$ & & & $\begin{array}{c}0.2722^{\star *} \\
(0.017)\end{array}$ & $\begin{array}{l}0.1073 \\
(2.380)\end{array}$ \\
\hline Leisure time $\mathrm{e}^{\mathrm{a}}$ & $\begin{array}{c}-0.0475 \\
(0.716)\end{array}$ & $\begin{array}{c}0.1501 \\
(-0.360)\end{array}$ & & & $\begin{array}{c}-0.0249 \\
(0.738)\end{array}$ & $\begin{array}{c}0.1356 \\
(-0.330)\end{array}$ \\
\hline Social relationship ${ }^{a}$ & $\begin{array}{l}0.2846 \\
(0.111)\end{array}$ & $\begin{array}{c}0.1778 \\
(1.59)\end{array}$ & $\begin{array}{c}0.3109^{* *} \\
(0.033)\end{array}$ & $\begin{array}{c}0.1665 \\
(2.14)\end{array}$ & $\begin{array}{l}0.2304 \\
(0.158)\end{array}$ & $\begin{array}{l}0.1613 \\
(1.410)\end{array}$ \\
\hline Health condition ${ }^{\mathrm{a}}$ & $\begin{array}{c}0.3678^{* *} \\
(0.049)\end{array}$ & $\begin{array}{c}0.1683 \\
(1.97)\end{array}$ & $\begin{array}{l}0.3208^{*} \\
(0.0510)\end{array}$ & $\begin{array}{l}0.1702 \\
(1.950)\end{array}$ & $\begin{array}{c}0.4513^{* * *} \\
(0.005)\end{array}$ & $\begin{array}{l}0.1581 \\
(2.830)\end{array}$ \\
\hline Chi-squared & 73.26 & & 67.13 & & 43.22 & \\
\hline p-value & $<0.001$ & & $<0.001$ & & $<0.001$ & \\
\hline Pseudo R-squared & 0.2043 & & 0.1751 & & 0.1230 & \\
\hline Log Likelihood & -148.745 & & -158.161 & & -163.76 & \\
\hline
\end{tabular}

\section{Discussion and Conclusion}

Based on the findings, high school teachers are considered as happy with their job. This means that they are satisfied with the nature of their work and possesses a good well-being, as they serve and impart knowledge to their students. In the study of Watt and Richardson (2007), and Fokkens-Bruinsma and Canrinus (2012), it is shown that teachers are likely to motivate their professional choice based on personal and social utility values and considering teaching as a mission. It's interesting to note that teachers' income and assets do not affect their happiness in teaching. This goes to infer that teachers do not after the benefits they can get in teaching career but rather the professional growth they might earn. This results is not consistent to the existing studies in happiness and income (Chaiprasit \& Santidhirakul, 2011; Frey \& Stutzer, 2010; Sadeghi et al., 2012). Our findings shows that they have low net income due to deductions from loans and amortizations, and also most of the teachers' academic rank is Teacher 1. In fact, several of these teachers are newly hired in Department of Education (DepEd) and not yet promoted to a higher rank. Other reason that income does not influence their happiness is that it is fixed, working harder as a public teacher does not mean to have higher salary. Although, other source of income is a great help for household expenses especially for those with large family size, but this has inverse effect to their happiness in teaching. This suggests that focusing on their other source of income, their teaching career is negatively affected. The result supports to the study of Guazzelli \& Zilli (2016), stated that teachers who participated in the survey demonstrated not be satisfied with the salary they receive as academicians.

Results reveal that demographic profile of teachers are not statistically significant factors to their happiness in teaching. This goes to infer that exogenous variables involved in the models do not affect the teachers' well-being, instead teachers' happiness is significantly influenced by job related experiences, social relationships and their health aspect. In the study of Bao and Lyubomirsky (2014), it is stated that a positive experiences occurring in contexts, individuals pursue intrinsic and self-determined goals that boost the effects of positive behavior in the long term. Among the teaching experiences, being creative contributes to the teachers' satisfaction and happiness which leads to a productive educator. Hence, it goes to infer that if teachers are being creative in the classroom environment, they explicitly invite the students to engage and have imaginative, evaluative and collaborative capacities in comprehending the lessons (Mertoğlu, 2018; Shyim \& Korb, 2016). Perhaps, being a creative teacher is having the quality or power of creating new ideas through their beliefs and value practices in their teaching career (Beghetto, 2016; Casinillo et al., 2020). Also, findings reveals that teachers are enjoying what they are doing, enjoying learning new things or researching new ideas to improve teaching strategies for quality academic performance of their students and this result is parallel to the study of Shoshani and Steinmetz (2013). This further indicates that teachers love what they are doing and pursuing growth without locking struggles with new ideas, making them efficient for the well-being of students in the classroom setting. 
Enjoyable experience will certainly help the teacher to have a positive attitude towards the students, good personal qualities, and excellent teaching style, too, which will surely have a positive impact on students' performance and teachers' professional growth (Casinillo, 2019). School environment is also a significant determinant of happiness in teaching. This suggests that a conducive place and positive institutional climate can eliminate stress and can positively affects the degree of subjective well-being (Mertoğlu, 2018; Singh, 2014). Bestowing to the findings, teachers are socially interactive and believe that their relationships give them emotional support and encouragement which positively increase happiness. Teachers portrays a friendly and approachable impressions to students and to their fellow other faculty members. This implies that teachers who are closely related to students and other faculty members results to feel comfortable and confident to do their job. According to the study of Macuka et al. (2017) and Markussen et al. (2018), it has emerged that positive interpersonal relationship for both colleagues and superiors leads to a higher degree of happiness at work. Findings show that if teachers are healthy, then there is a higher likelihood of being happy at teaching. This result is consistent to the studies of Macuka et al. (2017), and Veenhoven (2008), that deals with health and happiness. It is concluded that good health of the teachers increases their level of happiness in teaching which results to productivity and efficiency. In the study of Pressman et al. (2018), positive emotions on health outcomes revealed the buffering role of positive affect in stress conditions, developing illness and burnout disorders which results to low self-efficacy, and dissatisfaction at work. Perhaps, teachers at a lower risk for burnout at work results to good health, valuable feedback from colleagues and mentors, and feel they can improve students' ways of learning and thinking (OECD, 2014; Hiller et al., 2017)

\section{Recommendations}

Convincingly, it is recommended that another study should be conducted in any high school campus with larger sample size of teachers to gather more accurate information on the determinants of happiness. School administration and policy makers must consider the teacher's welfare conditions by giving medical incentives, limiting paper works and right to have vacations to relieve stress. School heads must initiate developments to the work assignments and benefits to come up with new policy to improve the well-being of teachers. Furthermore, a positive interventions in school helps strengthen positive organizational dimensions, teachers' psychological resources and promoting teachers' healthy behaviors. One constraint of this study is that it does not cover credits data, hence, it is strongly recommended for further empirical analysis on economics of happiness in teaching to include variables related to teachers' access to credit or loans for future research.

\section{Acknowledgement}

A sincere thanks to the reviewers for giving significant comments for the improvement of this paper.

\section{References}

Akomolafe, M.J., \& Ogunmakin, A. O. (2014). Job satisfaction among secondary school teachers: Emotional intelligence, occupational stress and self-efficacy as predictors. Journal of Educational and Social Research, 4(3), 487-498.

Allison, P. (2012). When Can You Safely Ignore Multicollinearity? Retrieved from http://statisticalhorizons.com/multicollinearity

Andersson, P. (2008). Happiness and health: Well-being among the self-employed. Journal of Socio-Economics, 37(1), 213-236.

Beghetto, R. A. (2016). Creative learning: A fresh look. Journal of Cognitive Education and Psychology, 15(1), 6-23.

Casinillo, L. F. (2019). Factors affecting the failure rate in mathematics: the case of Visayas State University (VSU). Review of Socio-Economic Research and Development Studies, 3(1), 1-18. 
Casinillo, L. F. \& Aure, M. R. K. L. (2018). Econometric evidence on academic performance in basic calculus of science, technology, engineering and mathematics (STEM) senior high students. Journal of Educational and Human Resource Development, 6, 238-249.

Casinillo, L. F., Camulte, M. C. G., Raagas, D. L. and Riña, T. S. (2020). Cultural factors in learning mathematics: the case on achievement level among Badjao students. International Journal of Indonesian Education and Teaching, 4(1), 71-81.

Casinillo, L. F. \& Guarte, J. M. (2018). Evaluating the effectiveness of teaching strategies: The case of a national vocational school in Hilongos, Leyte. Review of Socio-Economic Research and Development Studies, 2(1), 64-79.

Chaiprasit, K. \& Santidhirakul, O. (2011). Happiness at Work of Employees in Small and Medium-sized Enterprises, Thailand. Procedia - Social and Behavioral Sciences, 25(1), $189-200$.

Cochran, W. G. (1953). Sampling Techniques. New York: John Wiley and Sons, Inc.

Dağli, A and Baysal, N. (2017). Investigating teachers' life satisfaction. Universal Journal of Educational Research, 5(7), 1250-1256.

Fisher, C. D. (2010). Happiness at work. International Journal of Management Review, 12, 384-412. doi: 10.1111/j.1468-2370.2009.00270.x

Fokkens-Bruinsma, M., and Canrinus, E. T. (2012). Adaptive and maladaptive motives for becoming a teacher. Journal of Educational Teaching. 38, 3-19. doi: $10.1080 / 02607476.2012 .643652$

Frey, B. and Stutzer, A. (2010). Happiness: A New Approach in Economics, CESifo DICE Report, Center for Research in Economics, Management and the Arts, Switzerland.

Ghavifekr, S. \& Rosdy, W. A.W. (2015). Teaching and learning with technology: Effectiveness of ICT integration in schools. International Journal of Research in Education and Science, 1(2), 175-191.

Golden, L., Henly, J., and Lambert, S. (2013). Work schedule flexibility: a contributor to employee happiness? Journal of Social Research Policy, 4, 1-32.

Guazzelli, G. P. and Zilli, J. B. (2016). Economics of happiness: A study on happiness indicators in university professors. Ecoforum, 5(1), 171-181.

Greene, W. H. (2008). Econometric Analysis. $6^{\text {th }}$ edition. New Jersey: Prentice Hall, Upper Saddle River.

Helliwell, J., Layard, R. \& Sachs, J. (2012). World Happiness Report. New York. Earth Institute.

Hiller, J., Schatz, K., and Drexler, H. (2017). Gender influence on health and risk behavior in primary prevention: a systematic review. Journal of Public Health, 25, 339-349. doi: 10.1080/09540121.2016.1139038

Kahnemann, D. \& Deaton, A. (2010). High income improves evaluation of life but not emotional well-being. Proceedings of the National Academy of Sciences, 107(38), 16489-16493. Retrieved from https://doi.org/10.1073/pnas.1011492107

Lyubomirsky, S. \& Lepper, H. S. (1999). A measure of subjective happiness: Preliminary reliability and construct validation. Social Indicators Research, 46(1), 137-155.

Macuka, I., Buric, I., and Sliskovic, A. (2017). Emotional experiences as predictors of teachers' mental health. Psychology Topics, 26, 355-375.

Markussen, T., Fibæk, M., Tarp, F. \& Tuan, N. D. A. (2018). The Happy Farmer: SelfEmployment and Subjective Well-Being in Rural Vietnam. Journal of Happiness Studies, 19(1), 1613-1636.

Mertoğlu, M. (2018). Happiness level of teachers and analyzing its relation with some variables. Asian Journal of Education and Training, 4(4), 396-402

OECD. (2014). TALIS 2013 results: an International Perspective on Teaching and Learning. Paris: OECD.

O'Connell, A. A., \& Liu, X. (2011). Model diagnostic for proportional and partial proportional odds models. Journal of Modern Applied Statistical Methods, 10(1), 139-175.

doi:10.22237/jmasm/1304223240 
Pressman, S. D., Jenkins, B. N., and Moskowitz, J. T. (2018). Positive affect and health: what do we know and where next should we Go? Annu. Rev. Psychol. 70, 627-650. doi: 10.1146/annurev-psych-010418-102955

Proto, E. (2016). Are happy workers more productive? IZA World of Labor, 315, 1-8.

Sadeghi, J. M., Shirouyehzad, L. \& Samadi, S. (2012). Estimating the impact of education on income with econometric approach: A case study in universities. International Journal of Academic Research in Business and Social Sciences, 2(6), 2222-6990.

Schiffrin, H. H., \& Nelson, S. K. (2010). Stressed and happy? Investigating the relationship between happiness and perceived stress. Journal of Happiness Studies, 11(1), 33-39.

Sharp, J. (2012). Success with your education research project (2nd ed.). Sage. London, England.

Shoshani, A. \& Steinmetz, S. (2013). Positive psychology at school: A school based intervention to promote adolescents' mental health and well-being. Journal of Happiness Studies, 15(6), 1289-1311.

Shyim, E. C., \& Korb, K. A. (2016). Factors contributing to the life satisfaction of secondary school teachers in Jos North LGA. Journal of Educational Foundations, 6(1), 27-36.

Singh, A. (2014). Conducive Classroom Environment in Schools. International Journal of Science and Research, 3(1), 387-392.

Stock, J. H. \& Watson, M. W. (2007). Introduction to Econometrics. $2^{\text {nd }}$ edition. Boston: Pearson Addison Wesley.

Štreimikienè \& Grundey. (2009), Life satisfaction and happiness-the factors in work performance. Guest Editorial, Economic \& Sociology, 2(1), 9-26.

Veenhoven, R. (2008). Healthy happiness: effects of happiness on physical health and the consequences for preventive health care. Journal of Happiness Studies, 9, 449-469.

Watt, H. M. G., and Richardson, P. W. (2007). Motivational factors influencing teaching as a career choice: development and validation of the FIT-choice scale. Journal of Experimental Education, 75, 167-202. doi: 10.3200/JEXE.75.3.167-202

Williams, R. (2016). Understanding and interpreting generalized ordered logit models. The Journal of Mathematical Sociology, 40(1), 7-20. doi:10.1080/0022250X.2015.1112384.

Wolf, E. \& Beblo, M. (2004) Does Work Time Flexibility Work? An Empirical Assessment of the Efficiency Effects for German Firms, Discussion Paper No. 04-47 (Mannheim, Germany, Centre for European Economic Research (ZEW)). 